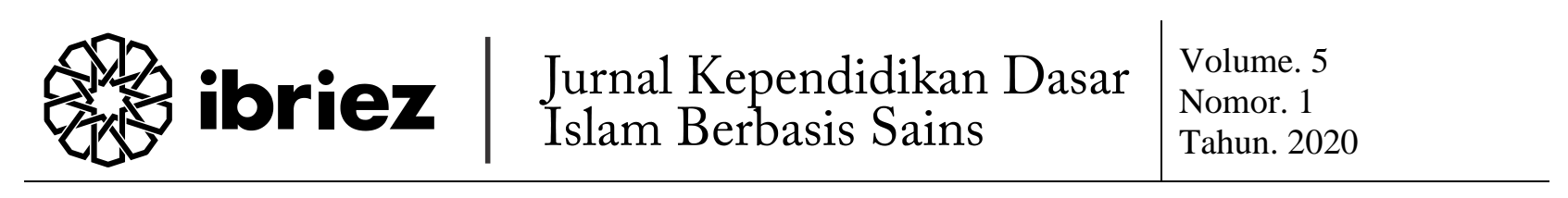

\title{
Language and Brain: Maximizing Children's Brain in Learning Foreign Language Through Storytelling, Songs, and Flashcards
}

\author{
Niswatin Nurul Hidayati \\ Institut Agama Islam Al Hikmah Tuban \\ niswatinnh@gmail.com
}

\begin{abstract}
Abstrak
Usia dini merupakan usia untuk bermain bagi anak anak. Di samping itu, usia itu juga waktu dimana otak anak mampu menyerap banyak hal. Oleh karena itu menggunakan media bermain untuk memaksimalkan otak anak, khusunya dalam bidang penguasaan Bahasa sangat penting. Tentu saja banyak cara yang dapat digunakan, namun dalam tulisan ini, penulis berfokus pada penggunaan storytelling, songs, serta flashcards sebagai media untuk memaksimalkan pembelajaran Bahasa asing pada anak. Bahasa menjadi salah satu hal yang penting untuk dikembangkan selain ranah kognitif. Mempelajari Bahasa asing di usia dini dipandang baik karena akan menancap di otak anak daripada mempelajarinya di usia dewasa. Salah satu bagian yang ditekankan adalah terkait penguasaan kosakata yang akan menjadi bekal untuk penguasaan kemampuan yang lain, misalnya kemampuan menulis, membaca, mendengarkan dan berbicara.
\end{abstract}

Kata Kunci: Bahasa dan otak, Bahasa asing, anak, bercerita lagu anak, kartu bergambar

\begin{abstract}
Early age is the age to play for children. In addition, early age is also a time when the child's brain is able to absorb many things. Therefore, using playing media to maximize the child's brain, especially in the field of language mastery is very important. Of course, there are many ways that can be used, but in this paper, the author focuses on the use of storytelling, songs, and flashcards as a medium to maximize foreign language learning in children. Language becomes one of the important things to be developed besides the cognitive domain. Learning foreign languages at an early age is considered good because it will stick in the brain of a child rather than learning it in adulthood. One part that is emphasized is related to the mastery of vocabulary that will become a provision for mastering other abilities, such as the ability to write, read, listen and speak.
\end{abstract}

Keywords: language and brain, foreign language, children, storytelling, children's song, flashcards 


\section{A. INTRODUCTION}

We have already known that brain development depends on the complexity of the relationship between genes carried by a person and the experiences that have occurred to that person since he was born. Quoting from what was delivered by Aamodt \& Wang, Berk, Diamond \& Hopson, Fox, Levit \& Nelson, also Nagel that experience is important to accelerate cognitive capacity. ${ }^{1}$ A similar thing was also conveyed by Chugani who said that the environment was indeed something very important for brain development at an early age or at an early stage of development, because the more the experience was repeated then the opportunity to become something permanent in the brain was also higher. ${ }^{2}$

This surely can be attributed to the process of language learning in early childhood. Quoting from The Asian Parent Indonesia, it is mentioned that at the stage of brain development of children, vocabulary learning starts from birth until the age of 3 years, especially between 6 to 12 months. Relating to the second language, its development is at the vulnerable age of 6 to 10 months. In this short paper, the author will focus on the learning process of English.

Studying Foreign Languages, in this context English is not a new thing in Indonesia. Learning one language seems to be a "must" for everyone who wants to keep abreast of the times. This is because

\footnotetext{
${ }^{1}$ Nagel, "The Brain, Early Development and Learning."

${ }^{2}$ Chugani, "Neuroimaging of Developmental Non-

Linearity and Developmental Pathologies," 187-195.
}

almost every information from outside our country is acknowledged or not delivered in this language, be it in the realm of technology, education, medicine, engineering, or research results. This could be the reason for parents who introduce English to their children from the beginning, either by entering it into a course institution or an international school. The same was expressed by Nadiem Makarim in his speech related to the Development of Indonesian Human Resources Towards a Digital Economy, where he mentioned that the four components that needed to be present and mastered were, English, Programming and Computer Coding, mentorship and coaching, and statistics and psychology.

If we look at kindergarten, we certainly find the process of introducing English in several ways, for example by singing, flash cards, and storytelling.

We recognize the existence of golden ages in children where the child's brain is able to absorb any information around it. This is what must be realized, both by the teacher and parents in order to be able to maximize this period. The teacher of course is also a factor that strongly supports the child's success in learning something especially in English because the child gets it from his teacher. So that teacher capabilities must be considered so that the transfer of knowledge in the form of an introduction to English will run well. ${ }^{3}$

When teaching a language to children, of course it will be easier if supported by

\footnotetext{
${ }^{3}$ Hidayati, "Meningkatkan Kosakata Bahasa Inggris Anak Usia Dini Dengan Kartu Bergambar."
} 
the media. As mentioned earlier that there are quite a lot of media that can be used, in this case the writer will focus on the use of storytelling, songs and flashcards.

\section{B. FOREIGN LANGUAGE}

English is one of the foreign languages learned in Indonesia. If we talk about English, the components that should be mastered are listening, reading, speaking, and writing. But of course, we cannot teach it directly to children, because it is too complex. What must be done is to equip the children so that later mastery of the four points above can be carried out well. The provision is in the form of mastery of vocabulary. Vocabulary is a simple thing that is suitable to be taught to children.

Quoting Freudenstein's writing, there are three advantages when learning a foreign language at an early age, consisting of: 4

1. Intellectual improvement; children who learn foreign languages appear to have a higher mental level, they are better than monolingual children both at verbal and nonverbal abilities at the same age.

2. Mother tongue improvement; It is incorrect to say that learning a foreign language will interfere with the development of the mother tongue or even interfere with its acquisition. Learning it will help children to understand their mother tongue system better. basic

\footnotetext{
${ }^{4}$ Freudenstein, "Issues and Problems in Primary Education."
}

development of a child's mother tongue will end at the age of four or five years. There is plenty of evidence to suggest that bilingual or multilingual children throughout the world have no difficulty as a result of knowing or using several languages effectively in their daily communication.

3. Cultural gains; learning foreign languages can support the growth of individual character quality and it has an important role in character development.

Then, quoting from the writings of Alison Mackey, where he mentioned that learning a foreign language would be able to increase brain size. This research is the result of a study of Swedish scientists who discovered this fact when they used brain scans to observe what happens when someone learns a second language. ${ }^{5}$

In addition to the benefits conveyed by Freudenstein above, learning in childhood will be very helpful because at this time children are very enthusiastic about learning, playing with people, understanding something in their environment, which is detailed by Scott and Ytreberg which mentions some of the characteristics students or early childhood, consisting of: 6

1) They know that the world is governed by several rules. They may not always understand the rules, but they know that they are here to obey them and

\footnotetext{
${ }^{5}$ Mackey, "What Happens in the Brain When You Learn a Language?"

${ }^{6}$ Scott and Ytreberg, Teaching English to Children.
} 
the rules help them to maintain a sense of security.

2) They understand a situation faster than understanding the language it uses.

3) They use language skills long before they understand the language

4) Their own understanding comes from the hands, ears and eyes. The physical world becomes dominant.

5) They are very logical - what you say first will happen first

6) They have very short concentration and attention time

7) They sometimes have difficulty in knowing or understanding what is fact and what is fiction

8) They like to play together with other people

9) They do not always understand the world of adults

10) They will very rarely admit that they don't know something

11) They cannot determine what they must learn for themselves

12) They love to play, and will quickly learn when they feel comfortable, but they also like themselves and like to think that what they are doing is "real" work

13) They are very enthusiastic and positive when learning something. It's important to praise them when they keep their spirits up and feel successful from the start.

From the points above, it can be seen how great the benefits of learning a foreign language from an early age. This of course breaks the assumption so far that spread that teaching foreign languages to children will complicate the mastery of language in children. In fact, according to research conducted by Peal E. and Lambert W., it is stated that bilingual children outperformed the children of grammar in almost all tests carried out, including non-verbal intelligence. In another study, he also mentioned that bilingual children are more likely to be exposed to Alzheimer's more slowly than monolingual children. ${ }^{7}$ Tirto.id also mentioned several other things related to bilingualism, for example that the more a child is exposed to more than one language, the faster it will be mastered, when learning, children will mix two languages, children must be accustomed to interact with the second language at least $30 \%$ per day. Then, the language environment experienced by children influences the quality of the cognitive system they develop.

\section{LANGUAGE AND CHILDREN'S BRAIN}

As we know that the human brain is divided into two parts, they are the left brain and right brain. The left brain has functions related to analytical thinking, logic, language, science and mathematics. While the right brain is more on intuition, creativity, art and music. Of course, these two hemispheres have the same important role in the growth and development of children.

According to Joan Freeman and Utami Munandar, there are several characteristics of children who are dominated by certain brain hemispheres, consisting of: ${ }^{8}$ children who are dominated by the right hemisphere usually

\footnotetext{
${ }^{7}$ Bhaskara, "Seberapa Besar Manfaat Dwibahasa Untuk Anak-Anak? - Tirto.ID."

${ }^{8}$ Chamida, "PENTINGNYA STIMULASI DINI BAGI TUMBUH KEMBANG OTAK ANAK*)."
} 
like to study in groups, do not like to sit and lack of learning, love to move, hold, touch, and do something, achievement at school is less brilliant, and enjoys a dim light and warmth. Then, children who have left brain dominance have the characteristics of being happy to learn alone, independent, persistent and hardhearted, sitting quietly when studying, good school performance, and happy formal teaching.

Kisilevsky et al. and Peranti et al. mention that Neural networks for language acquisition are fully formed before birth; babies are able to perceive and react to sound as early as at 24 weeks gestation and begin to learn languages in utero by 35 weeks gestation, suggesting that newborn infants' brains are primed to learn languages. ${ }^{9}$

Quoting from the page of The Asian Parent Indonesia, it is mentioned that your child's brain works hard enough to develop in the early days of his life when he absorbs the meaning of everything that happens around him. He learns and remembers how all the things in the world work through the 5 trusted senses, consisting of sight, hearing, smell, touch and feel.

Stimulation of a child's brain development can be done by using food or other media to stimulate, for example by playing. Foods that contain anti-oxidants and omega- 3 fatty acids (DHA) have been believed to be mandatory foods that help your child's brain development. You can also find this substance in some types of milk substitutes for breast milk. ${ }^{10}$

\footnotetext{
${ }^{9}$ Head Zauche et al., "The Power of Language Nutrition for Children's Brain Development, Health, and Future Academic Achievement-Continuing Education Posttest."

10 "Tahap Perkembangan Otak Anak, Bagaimana Menstimulasinya? | TheAsianparent Indonesia."
}

In the following we will discuss each stage of a child's brain development from pregnancy to 10 years:

\section{Pregnancy period}

Maternal health before pregnancy is very important for the growth of the baby and the baby's brain. Good nutrition, avoidance of alcohol and drugs are the best things that can be done for the unborn child. Foods that contain Omega 3 or DHA are very good for the baby's brain development, especially in the 7th month of pregnancy until breastfeeding period.

\section{When the baby is born}

Babies are born with more than 100 billion brain cells. These cells help control the main functions in the body such as breathing to more complex functions such as intellectual functions.

During the child's growing period, connections between 100 billion cells occur. Connections occur when children experience something new by involving their senses. Patting, talking, smiling, and introducing babies to new views, smells, and tastes can stimulate the connection of brain cells. The more this experience is repeated, the stronger the connection is formed. Only positive experiences help the child's brain development, while negative experiences can cause emotional, behavioral, and learning problems. At around the age of 3 , connections between cells are most common. 
The stages of child brain development

The following are periods of child brain development that we can use to maximize the development of intelligence:

- Motor development: during pregnancy up to 5 years

- Emotional development: from birth to 2 years (the most sensitive is between 10-18 months)

- Vision: from birth to 2 years (especially between 2-4 months and 8 months)

- Vocabulary: from birth to 3 years (especially between 6-12 months)

- Second language: between 6-10 months

- Logic/mathematics: from birth to 4 years

- Music: from birth to 10 years

By knowing the child's brain development period, we can have a positive influence at each of these stages so that the child becomes smarter. For example, to teach a lot of vocabulary and language skills, do especially at the age of 6-12 months. Inviting a child to talk even though he may not understand, is the most effective way to stimulate language development.

Meanwhile, to introduce other languages, do it at the age of 6-10 months. Because the development of language skills occurs from birth to 3 years, it is not surprising that many parents admit that their toddlers learn a lot of English vocabulary from English-language children's shows on TV. Likewise, when choosing children's toys, choose according to each stage of its development in order to stimulate the development of intelligence, motor, emotional, and logic.

Swedish scientists say that the size of the brain expands and becomes larger when he learns a second language. This is observed by using a brain scan when someone is learning a second language. Alison Mackey also wrote that what was more encouraging was that people or children who learned a second language had more advantages than those who did not, and the results of the study showed that 853 of their participants mentioned that knowing other languages outside their language was indeed beneficial, regardless of when we learn it. ${ }^{11}$

\section{WAYS TO MAXIMIZE CHILDREN'S BRAIN}

There are several ways or media that can be done to be able to maximize the brain of children in learning a foreign language, for example in this context it is linked to the use of media, such as storytelling, songs, and flashcards.

Media can be interpreted as an intermediary, which is very important in the process of early childhood learning, because at that time they liked to play. So, by playing it, the learning process is inserted, in this case language learning. This is like what Scott and Ytreberg said that Children have an amazing ability to absorb language through play and other activities which they find enjoyable. ${ }^{12}$

\footnotetext{
${ }^{11}$ Mackey, "What Happens in the Brain When You Learn a Language?"

${ }^{12} \mathrm{Scott}$ and Ytreberg, Teaching English to Children.
} 
Gerlach \& Ely states that media are human, material, or events that create conditions that make students able to gain knowledge of skills or attitudes. There are several types of media that are often used in Indonesia, for example 1) visual media/graphic media, it is media that can be seen for example pictures/photos, sketches, diagrams, charts, graphs, cartoons, posters, maps and globes, flannel boards and bulletin boards; 2) audio media, media related to the sense of hearing; 3) projection media (audiovisual). ${ }^{13}$

\section{a) STORYTELLING}

National Council of English Teachers stated that storytelling is "relating a tale to one or more listeners through voice and gesture" Andrews in his book entitled "Story Types and The Hero Story" states that storytelling has been used for tens of thousands of years to tell stories, history unwritten values and culture. ${ }^{14}$

The use of media in the form of storytelling has many uses, one of which is to increase the diversity of vocabulary possessed by children, besides as a way to instill moral values. As mentioned earlier in the background, learning vocabulary, especially English, will support other abilities in this language, for example

\footnotetext{
${ }^{13}$ Latif, Orientasi Baru Pendidiikan Anak Usia Dini. 14 Niswatin Nurul Hidayati. "Storytelling: One Package Learning In Improving Language Skill And Implanting Character Education On Children". EDUKASI: Jurnal Pendidikan Islam 7 (2), 53 - 72. https://doi.org/10.5281/edukasi.v7i2.390.
}

listening, reading, writing and speaking abilities.

We know the term that studying at a young age is like carving on a stone, whereas learning at an adult age is like carving on water. The same thing should apply to learning a foreign language, when at an early age especially in golden ages, will help children enrich their knowledge so that it will be very useful in the future.

Learning through media storytelling has some advantages. Eisner identifies the two most important contributions of aesthetic ways of knowing for the field of education as the referential and the consummatory functions. He describes the referential function as students' ability to appreciate and understand the qualities conveyed in learning. The consummatory function is understanding the importance of the journey and being able to find joy in the inquiry along the way. Through storytelling these functions have the opportunity to flourish as students develop their literacy skills within the classroom. ${ }^{15}$

Related to the use of storytelling in the language learning process, there are several writings that have discussed this theme, for example Hidayati's writing titled Storytelling: One Package Learning in Improving Language Skills and Implanting Character Education On Children. In his writing, he discusses how

\footnotetext{
${ }^{15}$ Miller and Pennycuff, "The Power of Story: Using Storytelling to Improve Literacy Learning."
} 
storytelling has the benefit of being a means of learning from two things at once, namely language learning and moral values and character.

So that the language learning process through this media runs well, then there are some tips that can be done, consisting of: 16

1) Every part must be essential

If you use stories or create stories for the learning process, then you must ensure that the sections in your story will lead to your final goal. For example, when you tell about the names of the planets, then ignore the contents of the story relating to black holes, supernovae or others.

2) You must have a hook in your opening

When you tell stories, make your listeners or students interested to continue listening to you. This you can do by creating or showing a problem. Suppose you tell a story about photosynthesis, then you can start your story by asking them to imagine a world without leaves.

3) Draw a theme out of your story The story will have a deep meaning if it has a theme. You can relate it to past and present events, and relate it to real life.

4) Keep it simple

If your audience is children, then you should avoid complex stories. Use simple stories so they can easily understand them.

${ }^{16}$ DeNeen, "30 Storytelling Tips For Educators: How To Capture Your Student's Attention."
5) Maintain eye contact Eye contact is one of the most important non-verbal ways to connect you to other people. This will keep your students paying attention to you, and this will make them feel assured and confident.

6) Use vivid language that kids can understand

Some psychologists say that storytelling is one of the main ways used by humans to learn. If for example you tell your students about concepts of science or mathematics, you can name one or two words that they have never heard before. Then, you describe the words and use them throughout your story. Then, at the end of your story, they will understand the meaning of the word while remembering the vocabulary.

7) Use movement

When you tell a story, use certain movements, for example using your hands, feet, or head. You can also ask your students to demonstrate certain movements. This will help them concentrate and focus on what is done.

8) Use dramatic pause

When you read a story, use dramatic pause on some scenes or problems that don't seem to be solved. This will make the listener try to find a solution to the problem or think about it.

9) Change your voice with different characters

When you are able to mimic certain sounds from the characters you tell 
in your story, it will make your students remember them more.

10) Make your ending strong with an important take away point

Ending is the last thing your students will hear. Whatever your main points, then put it behind. If you are able to make it in one sentence then it will be better. For example, if you talk about freedom, then there are sentences like "The Civil War taught Americans that everyone is free to love, free to pursue their dreams, and free to be free"

11) Tell the truth, even when it's difficult

Adults usually tend to lie to children when there are difficult or too complex situations. However, speaking honestly is always better even if you have to concoct your sentence details to be understood by children.

12) Make the character relatable When you tell a story, the main character of your story must relate to your students. You don't have to be human, you can even make recycled paper as a good person and aerosols can be enemies or bad people when you're talking about pollution.

13) Have your story provide an answer to a problem

Every story you tell has a theme. When you are able to provide solutions to existing problems, they will save them so they can be used to solve problems in real life.

14) Know your ending before you begin
You have to understand where the end of your story is, so that you don't jump here and there while telling stories.

15) Appeal to their senses

Humans have a variety of senses, consisting of sight, sound, taste, and smell. When you tell stories and you activate all of these senses, the story will be more memorable.

16) The story should be "trustable" When you tell a story, don't change the rules of the universe just to make the problem in the story magically finish. Don't break the rules just to end the story.

17) Invite interaction

At certain times, you can ask your students what might happen next, or even the end of the story.

18) Make the stakes high against the goal

Stories with a happy ending must go through obstacles first. Before you end the story, then create a dramatic tension that makes your listener think whether the character is able to arrive at its destination.

19) Use props

Property has always been an important thing to use. In the use of property, do not you remove all the properties at once, your name one by one when you tell stories. You can even ask your students to hold or use the property.

20) Create the extraordinary out of the ordinary

When you tell a story, you can see things from a different perspective 
so that it can make a story that can be extraordinary.

21) Set the scene

It's important to create an environment in your story in detail. So, your students see it in their imagination, whether they are on the beach, in the forest or in an apartment in a big city.

22) Use music

Music is one method that can be used to memorize a long list of things. For example, if you teach children to memorize 50 state names, for example, using music will make it easier for them. Music is also one of the ways that many cultures use to keep their traditions and history memorable.

23) Create fun sound effect

The existence of sound effects will make the scenes created become richer.

24) Have your students; retell it back to you

When you have finished telling a story, you can ask them to create a group to tell it back to you.

25) Draw real life connections

When you talk about something abstract, then what you need to do is make it into a real example in everyday life.

26) Use repetition

When you tell a story, then you should repeat the main theme or point, especially if your audience is children. You can repeat this at the beginning, middle or end. You can also express the same thing with different sentences.
27) Write your story in one sentence before you begin

In order to keep your story simple and focused on what's important, narrow it down to one sentence. Start with the beginning, and then add the middle, and the end. In the sentence, you should get the main purpose of the story, as well as the competing concept that threatens the story's goal.

28) Avoid detours

Cut out characters, scenes, and information that do not somehow work towards the goal of the story.

29) Create a timeline Write a timeline of events for you to keep track of the order. You can even put up an empty timeline on the board, and as you tell the storyadd the important events as they happen.

30) Don't give away too much

When you tell a story that has some mystery, you invite the listeners to try to figure out the solution for themselves. When they do, chances are- it will be more memorable and long lasting.

\section{b) SONGS}

When we observe the learning process in kindergarten or Islamic Kindergarten, or other educational institutions that have students at an early age, then the song becomes one of the most frequently used methods. The same thing can also be used in the process of learning a second language or a foreign language. This is one of them shown in the research of Miranti 
et al. with the title "The Use of Children's Song Media in Developing Students' English Vocabulary Abilities in PAUD". The study was conducted at PAUD Al Amin, Cibeureum Village, where this study had a target to improve the ability of teachers to teach English vocabulary and early childhood children who were more receptive to the material being taught. ${ }^{17}$

Heinich and Molenda also mentioned that one of the music or audio media is media that can be used in the learning process, where in theory he mentions that there are 6 media that can be used, consisting of:

a. Text, is a basic element in conveying information that has various types and forms of writing that strive to provide attraction in the delivery of information.

b. Audio media, helps convey information more memorable and helps increase the attractiveness of an offering. Types of audio include background sound, music or voice recording and others.

c. Visual media, media that can provide visual stimuli such as pictures/photographs, sketches, diagrams, charts, graphs, cartoons, posters, bulletin boards, and others.

d. Motion projection media, including motion films, bracelet films, TV programs, video tapes (CD, VCD or DVD)

\footnotetext{
${ }^{17}$ Ira, "PENGGUNAAN MEDIA LAGU ANAKANAK DALAM MENGEMBANGKAN KEMAMPUAN KOSAKATA BAHASA INGGRIS SISWA DI PAUD."
}

e. Artificial/miniature objects, including three-dimensional objects that students can touch and touch. This media is made to overcome the limitations of both objects and situations so that the learning process continues to run well.

f. Humans, including teachers, students, or experts in certain fields/materials.

Miranti, Engliana and Hapsari, there are several benefits in the process of teaching English using songs, consisting of: 18

a. Through songs will motivate children to be happier to learn English.

b. By singing children become happy and easier to understand the teaching material delivered. The ability of teachers to choose songs and create movements that are appropriate to the age of child development will also affect the success of the process of learning English in early childhood.

c. Through various songs and learning activities, educators can foster children's interest to be happier and active in learning, and can even make it easier for children to understand the teaching material delivered.

d. Children are made happy, not bored, and interested in following the learning process. Thus, singing

\footnotetext{
${ }^{18}$ Kasdi and Wijayanti, "PEMBELAJARAN BAHASA INGGRIS EFEKTIF MELALUI LAGU ANAK-ANAK UNTUK SISWA MADRASAH IBTIDAIYAH."
} 
is an activity that is very liked by children.

Nurhayati said a song researcher stated that before using songs as a teaching medium for elementary school children teachers should choose songs that are simple and in accordance with learning needs. Also choose songs whose lyrics can be heard clearly, also pronunciation is correct. Because students will use the song as a model so naturally they must find the best model. If the teacher will sing it, then it must also be ensured that the teacher will provide a good model for students. ${ }^{19}$

Then, the teacher must also pay attention to the steps he must take when teaching English to children. Suprijono said that there are several steps that must be done, as follows: ${ }^{20}$

a. Introducing songs to children should begin with an initial explanation of the theme of the English song to be sung.

b. The song is sung by the teacher for the first time and asks the child to listen to it.

c. Students are asked to sing songs with the teacher with a slow rhythm or tempo.

d. Teachers and students interpret songs into the correct Indonesian language

\footnotetext{
${ }^{19}$ Pembelajaran and 2009, "Penggunaan Lagu Dalam Pembelajaran Bahasa Inggris Untuk Siswa SD; Mengapa Dan Bagaimana."

${ }^{20}$ Kasdi and Wijayanti, "PEMBELAJARAN BAHASA INGGRIS EFEKTIF MELALUI LAGU ANAK-ANAK UNTUK SISWA MADRASAH IBTIDAIYAH."
}

e. The teacher and students sing the song together repeatedly from the slow tempo to the actual rhythm or tempo.

f. The teacher appoints students in groups or individually to sing English songs in front of the class

\section{c) FLASCARDS}

As it is known that childhood is a time of play. So, learning at that time should have been tucked in also through playing. Flashcards is a game using cards that have been given pictures and vocabulary, where later children will be given the opportunity to guess or say the name of the animal, in this case mention it in English.

In this case the role of the people around the child, both parents and teachers who use this method is crucial. We know that children easily imitate what they see and hear. Thus, the ability of the teacher as an English teacher must also be well considered. When the teacher is not correct in the mention or pronunciation of vocabulary, it may be imitated by children and carried up to the next level of education.

Hasan said that a flashcard is a card game that is done by showing images to children one by one quickly to trigger the child's right brain to be able to receive the information in front of them, and is very effective to help children learn to read by remembering pictures and shapes, and increasing vocabulary at an early age. He also 
mentioned that flash cards have many benefits, for example a) can read at an early age b) develop right brain memory c) practice toddlers concentration ability d) increase vocabulary from toddlers and e) children will be able to get two benefits at once, understand English and know the types of animals, fruits, vegetables, etc. $^{21}$

More specifically, Hasan mentioned the benefits of flash card media, consisting of: ${ }^{22}$

a) Being able to read at an early age

b) Developing right scrambled memory

c) Practicing toddlers' concentration skills

d) Children will get two benefits at once, understand English and know the types of animals, vegetables, fruit, etc.

\section{E. CLOSING}

\section{Conclusion}

From what has been discussed above, it is mentioned that the child's brain is able to accept many things at a young age so it needs to be increasingly triggered so that its development is more perfect, especially in mastering foreign languages. It has been mentioned that studying foreign languages at a young age provides quite a number

\footnotetext{
${ }^{21}$ Lestari, "Upaya Peningkatan Penguasaan Kosakata Bahasa Inggris Anak Melalui Media Kartu Gambar (Flash Card) Pada Kelompok B Di RA Barokah Klodran Karanganyar Tahun Pelajaran 2011/2012 NASKAH PUBLIKASI."

${ }^{22}$ Hasan, Pendidikan Anak Usia Dini, 66.
}

of benefits, so there is no harm in maximizing the brain in learning this, either by using storytelling, flashcards, or with songs. Each way has its own uniqueness and strengths, and all three can be choices for our media to teach foreign languages to children.

\section{Suggestion}

The author suggests that further writers further discuss ways that can be used to maximize the child's brain, especially in learning foreign languages. In addition, suggesting good cooperation between teachers and parents in creating a good environment in the learning process of children so that the child's ability to develop properly. This is because the environment has a tremendous impact on the child because the age of the child is the age of a sponge where the child is able to absorb whatever is around him.

\section{REFERENCES}

Bhaskara, Ign. L. Adhi. "Seberapa Besar Manfaat Dwibahasa Untuk AnakAnak? - Tirto.ID." Accessed June 25, 2020. https://tirto.id/seberapabesar-manfaat-dwibahasa-untukanak-anak-ciiA.

Chamida, Atien Nur. "PENTINGNYA STIMULASI DINI BAGI TUMBUH KEMBANG OTAK ANAK*)." Yogyakarta, 2009.

Chugani, H. T. "Neuroimaging of Developmental Non-Linearity and Developmental Pathologies." In 
Developmental Neuroimaging:

Mapping the Development of Brain and Behavior. San Diego: Academic Press, 1997.

DeNeen, Julie. "30 Storytelling Tips For Educators: How To Capture Your Student's Attention." Accessed June 25, 2020.

https://www.opencolleges.edu.au/inf ormed/features/30-storytelling-tipsfor-educators/.

Freudenstein, Reinhold. "Issues and Problems in Primary Education." In Ideas and Issues in Primary ELT., edited by Chris Kennedy and Jennifer Jarvis. Walton on Thames: Nelson, 1991.

Hasan, Maimunah. Pendidikan Anak Usia Dini. Yogyakarta: Diva Press, 2009.

Head Zauche, Lauren, Ashley E. Darcy Mahoney, Taylor A. Thul, Michael S. Zauche, Arianne B. Weldon, and Jennifer L. Stapel-Wax. "The Power of Language Nutrition for Children's Brain Development, Health, and Future Academic AchievementContinuing Education Posttest." Journal of Pediatric Health Care 31, no. 4 (July 1, 2017): 504-5.

https://doi.org/10.1016/j.pedhc.201 7.02.003.

Hidayati, Niswatin Nurul. "Meningkatkan Kosakata Bahasa Inggris Anak Usia Dini Dengan Kartu Bergambar." AlHikmah : Indonesian Journal of Early Childhood Islamic Education 1, no. 1 (June 20, 2017): 67-86. https://doi.org/10.35896/ijecie.v1i1. 6.

Ira, Engliana2 Fitri Senny Hapsari3 Miranti. "PENGGUNAAN MEDIA LAGU ANAK-ANAK DALAM MENGEMBANGKAN KEMAMPUAN KOSAKATA BAHASA INGGRIS SISWA DI PAUD." Faktor Jurnal Ilmiah Kependidikan 2, no. 2 (November 19, 2015). https://journal.lppmunindra.ac.id/in dex.php/Faktor/article/view/382. Kasdi, Kasdi, and Dina Novita Wijayanti. "PEMBELAJARAN BAHASA INGGRIS EFEKTIF MELALUI LAGU ANAKANAK UNTUK SISWA MADRASAH IBTIDAIYAH." ELEMENTARY: Islamic Teacher Journal 4, no. 1 (January 26, 2017). https://doi.org/10.21043/ELEMENT ARY.V4I1.1931.

Latif, Muktar. Orientasi Baru Pendidiikan Anak Usia Dini. Jakarta: Kencana, 2014.

Lestari, Ikmala Yunita. "Upaya Peningkatan Penguasaan Kosakata Bahasa Inggris Anak Melalui Media Kartu Gambar (Flash Card) Pada Kelompok B Di RA Barokah Klodran Karanganyar Tahun Pelajaran 2011/2012 NASKAH PUBLIKASI." Universitas Muhamadiyah Surakarta, 2012.

http://eprints.ums.ac.id/id/eprint/1 9227.

Mackey, Alison. "What Happens in the Brain When You Learn a Language?," 2015.

Miller, Sara, and Lisa Pennycuff. "The Power of Story: Using Storytelling to Improve Literacy Learning." Journal of Cross-Disciplinary Perspectives in Education 1, no. 1 (2008): 36-43. http://citeseerx.ist.psu.edu/viewdoc/ download?doi=10.1.1.493.4765\&rep= rep1\&type=pdf.

Nagel, Michael C. "The Brain, Early Development and Learning." In Proceedings of the Australian Council for Educational Research: Research Conference, 62-67. Queensland: University of the Sunshine Coast, 2013.

https://research.usc.edu.au/vital/acc ess/manager/Repository/usc:10746.

Pembelajaran, L Nurhayati - Majalah Ilmiah, and undefined 2009. 
"Penggunaan Lagu Dalam

Pembelajaran Bahasa Inggris Untuk

Siswa SD; Mengapa Dan Bagaimana."

Journal.Uny.Ac.Id. Accessed June 25,

2020.

https://journal.uny.ac.id/index.php/

mip/article/viewFile/6151/5339.

Scott, Wendy. A., and Lisbeth H. Ytreberg.

Teaching English to Children. New

York: Longman, 1990.

"Tahap Perkembangan Otak Anak,

Bagaimana Menstimulasinya? |

TheAsianparent Indonesia." Accessed

June 25, 2020.

https://id.theasianparent.com/mema

hami-perkembangan-otak-anak. 
72 | 2020 